\title{
Communication \\ No Effect of Selective Maturation on Fruit Traits for a Bird-Dispersed Species, Sambucus racemosa
}

\author{
Kohei Koyama * $*$ and Mayu Tashiro \\ Laboratory of Plant Ecology, Department of Agro-Environmental Science, Obihiro University of Agriculture and \\ Veterinary Medicine, Inadacho, Obihiro 080-8555, Hokkaido, Japan \\ * Correspondence: koyama@obihiro.ac.jp
}

Citation: Koyama, K.; Tashiro, M. No Effect of Selective Maturation on Fruit Traits for a Bird-Dispersed Species, Sambucus racemosa. Plants 2021, 10, 376. https://doi.org/10.3390/ plants10020376

Academic Editor: Anna Traveset

Received: 3 February 2021

Accepted: 12 February 2021

Published: 16 February 2021

Publisher's Note: MDPI stays neutral with regard to jurisdictional claims in published maps and institutional affiliations.

Copyright: (c) 2021 by the authors. Licensee MDPI, Basel, Switzerland. This article is an open access article distributed under the terms and conditions of the Creative Commons Attribution (CC BY) license (https:// creativecommons.org/licenses/by/ $4.0 /)$.

\begin{abstract}
Selective abortion, also called selective maturation, is a phenomenon wherein maternal plants selectively mature ovules that have the potential to grow into higher-quality fruits, such as those that contain more seeds. We hypothesized that the effects of selective maturation on fruit traits could be influenced by the dispersal mechanism. However, to date, limited studies have been conducted on selective maturation in bird-dispersed fruits. Unlike self- or wind-dispersed species, bird-dispersed species would not selectively mature fruits that contain more seeds because they are not preferred by birds. Here, we investigated the effect of selective abortion on the fruit traits of a bird-dispersed species, elderberry (Sambucus racemosa L. subsp. kamtschatica). We performed a flower-removal experiment. Half of the inflorescences on each individual tree were removed for the treatment group, whereas the control group was not manipulated. We found that the flower-removed trees showed higher fruit sets, suggesting the existence of resource limitation. The number of seeds per fruit did not increase by the experimental treatment. Additionally, the control individuals did not produce larger fruits. The lack of effects on fruit traits supported our hypothesis that the effect of selective maturation on fruit traits may differ among species with different dispersal mechanisms.
\end{abstract}

Keywords: fruit size; fruit-to-flower ratio; ornithochory; fruit dispersal; seed dispersal; animal dispersal; wider choice; frugivore; dispersal syndrome; fruit syndrome

\section{Introduction}

Selective abortion is a phenomenon wherein maternal plants selectively abort lowerquality ovules or immature fruits before fruit maturation to mature only those fruits or seeds that are of a higher quality [1-7] and thereby save resources [3], though resource limitation is not the sole factor that controls abortion in plants [7-15]. The process of selective abortion also has been considered as a mode of developmental selection [5], which states that as a result of completion among genetically diverse embryos, higher-fitness ones, such as those with more vigor or more developmental stability [5,16], are selectively developed into mature seeds [8,17]. Two selective mechanisms can occur simultaneously: selective fruit abortion and selective embryo or seed abortion. In selective fruit abortion, ovaries or immature fruits that have a higher potential to mature into higher-quality fruit are selectively matured, while those with a lower potential are aborted [3,5,18-24]. In selective seed or embryo abortion, ovules within a single ovary that have the potential to mature into higher-quality seeds are selectively matured [25-29]. The existence of selective maturation has been confirmed via hand-thinning experiments (i.e., random removal of flowers, ovules, or immature fruits $[18,30])$, which are based on the wider-choice hypothesis. This hypothesis states that maternal plants that do not undergo hand-thinning have a wider choice of high-quality zygotes or embryos for selective maturation than plants that have experienced the artificial random removal of flowers [18,31,32]. Therefore, the widerchoice hypothesis predicts that fruits that escape self-thinning (i.e., spontaneous thinning by maternal plants $[18,30])$ are of higher quality than those escaped artificial random thinning [18]. 
Compared with numerous previous studies of the effects of selective abortion on seed and offspring traits, the effect of selective maturation on fruit traits has not been thoroughly investigated, and the results that have been published show species-dependent differences. We suggest that these differences could be explained in part by speciesdependent dispersal mechanisms. For wind- or self-dispersed (i.e., ballistic explosion or gravitational fall) species, fruits that contain more seeds have been considered to be higher quality $[3,7,18,23,33]$, because these fruits may minimize the cost of fruit production per seed $[3,23]$ and also because the seeds from these are selected under more intense pollen tube competition with excess pollens $[3,18,23,33]$. Supporting this, empirical evidence shows that maternal plants of wind- or self-dispersed species selectively matured seedier fruits ([3,7,18,23,24,34] but see [19]). By contrast, fruits with more seeds may not necessarily be of higher quality for bird-dispersed species because birds do not prefer seedy fruits $[35,36]$. Therefore, we hypothesize that unlike the cases of self- or wind-dispersed species, selective maturation does not influence seed number per fruit for bird-dispersed species. In general, birds prefer fruits that contain a larger portion of edible parts, such as pericarps and arils, compared with its total seeds $[35,36]$. Therefore, bird-dispersed plant species would selectively mature larger, but not seedier, fruits. On the other hand, some frugivorous birds are known to be limited in the size of fruits they can ingest [37], and several studies suggest that gape width limits the ability of frugivores to process large fruits [38]. Therefore, larger fruits may not always be preferred by bird dispersers. The results of these previous studies indicate that the definition of "high quality" fruits could differ among species with different dispersal types. Therefore, the effects of selective maturation on fruit traits should also be analyzed by taking dispersal mechanism into consideration.

Compared with numerous studies on self- or wind-dispersed species, only a few studies have investigated the selective maturation of bird-dispersed fruits. Guitián [20,21] investigated the selective fruit abortion process for mahaleb cherry (Prunus mahaleb), whose fruits are dispersed by birds and other animals [39,40]. Guitián [20] has experimentally shown that this species selectively matured larger fruits. Additionally, although the number of seeds per fruit was not reported in the article [20], the number of seeds per fruit should have been fixed to one, because P. mahaleb fruits are one-seeded drupes [39]. The larger but not seedier fruits may be of higher quality for this bird-dispersed species, and Guitián's results support our hypothesis that the selection criteria differ among species with different dispersal mechanisms. In another study, Thompson and Dommée [22] investigated jasmine (Chrysojasminum fruticans (syn. Jasminum fruticans)). The fruits of this species are berries [41], but we are unaware of any reliable scientific literature on the fruit dispersal mechanism of this species. Additionally, Thompson and Dommée did not investigate the fruit traits. Similarity, Collevatti et al. [14] found that pequi (piqui) trees (Caryocar brasiliense) selectively abort self-pollinated seeds. Although fruits of this species are drupes [42], the effects of selective abortion on fruit traits was not investigated in their study. Selective abortion was also reported for acorns of oaks (Quercus ilex [5] and Q. serrata [10]), which are dispersed by birds and animals by means of scatter hoarding after primary gravitational fall [43-46]. However, because acorns themselves are foods for their dispersers, their fruit traits cannot be directly compared with those of fruits that are primarily dispersed by birds, which is the main focus of the present study. Winsor [47] found evidence of selective fruit maturation for the common zucchini squash (Cucurbita pepo, Black Beauty Bush variety), but since the plant in question was a cultivar, and its dispersal agent may be absent among present-day wild taxa [48], their results cannot be directly compared with those of the other cases. Therefore, evidence to support our hypothesis is currently limited and further evidence is needed for bird-dispersed species. In this study, we investigated selective maturation on the fruit traits of elderberry (Sambucus racemosa L.) using experimental hand-thinning of inflorescences. We expected results similar to those for another bird-dispersed species $P$. mahaleb [20], i.e., the selective maturation of fruits that are larger but not seedier. 


\section{Results}

We compared the fruit set and fruit traits between individuals in the control (C) and treatment $(\mathrm{T})$ groups. For the treatment group, half of the infructescences on each tree were experimentally removed just after flowering. No manipulation was performed for the control individuals. Inflorescences from the treatment individuals showed a higher fruit set than those of individuals in the control group, though the significance level was slightly higher than the conventional critical level (GLMM (Gamma): $p=0.067$, Figure 1a). The number of seeds in healthy fruits ranged from two to four, but most fruits ( $>96 \%)$ were three-seeded for both groups, and the mean seed number within each fruit was very similar (C: 2.97 and T: 2.99 seeds per fruits) and did not significantly differ between the two groups ( $p=0.745$, Table 1$)$. Mean fruit volume of the control group was only slightly higher (C: 32.3 and T: $30.7 \mathrm{~mm}^{3}$ ), and no significant difference was found between the two groups (GLMM (Gamma): $p=0.704$, Figure $1 b$ ).

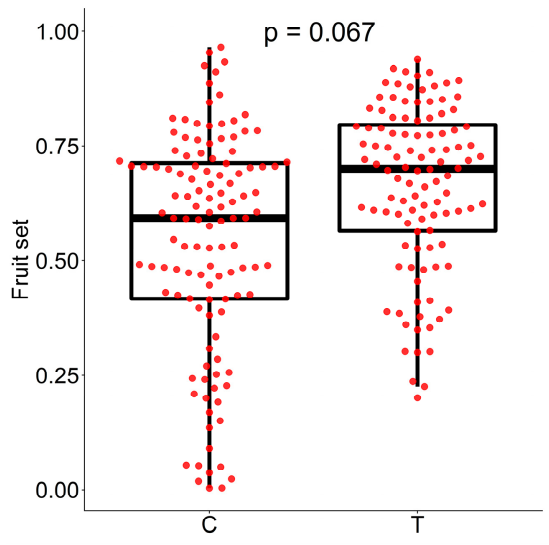

(a)

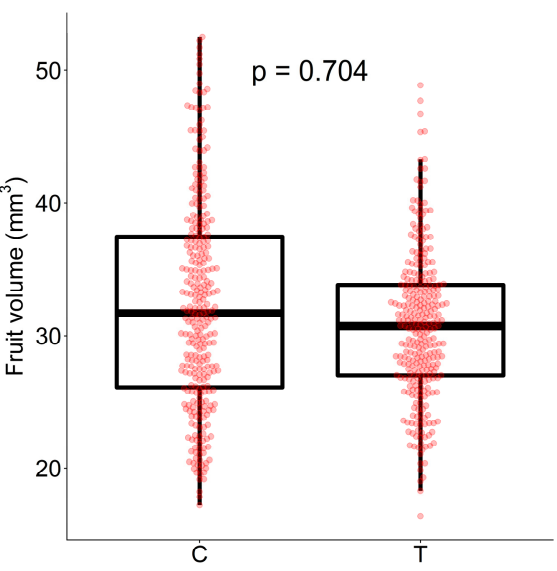

(b)

Figure 1. (a) Fruit set for inflorescences from the control (C) and treatment (T) individuals (12 control and 12 treatment trees). Each red closed circle indicates one inflorescence (i.e., bee swarm plots superimposed on box plots), and its vertical position indicates the value of the fruit set of that inflorescence. Each circle was shifted in the horizontal direction so as not to overlap with others ( $n=120$ and 108 infructescences for $C$ and T, respectively). The treatment group showed higher fruit set (GLMM (Gamma), $p=0.067$ ), supporting the wider-choice hypothesis. (b) The volume of the fruits (three treatment (T) and three control (C) trees). Each red circle indicates one fruit $(n=300$ fruits for each of $\mathrm{T}$ and $\mathrm{C})$. No significant difference was found between the two groups (GLMM (Gamma), $p=0.704)$.

Table 1. Seed number per fruit.

\begin{tabular}{ccccc}
\hline \multirow{2}{*}{$\begin{array}{c}\text { Number of Seeds } \\
\text { Within Each Fruit }\end{array}$} & \multicolumn{2}{c}{ Fruit Counts } & \multicolumn{2}{c}{ Relative Frequency (\%) } \\
\cline { 2 - 5 } & Control & Treatment & Control & Treatment \\
\hline 2 & 40 & 10 & $3.44 \%$ & $0.93 \%$ \\
3 & 1116 & 1066 & $96.04 \%$ & $98.70 \%$ \\
4 & 6 & 4 & $0.52 \%$ & $0.37 \%$ \\
Total & 1162 & 1080 & $100 \%$ & $100 \%$ \\
Mean seed number per & 2.97 & 2.99 & & \\
fruit & & & & \\
\hline
\end{tabular}

\section{Discussion}

We conducted a literature survey that covers previous studies on selective maturation. Currently, selective maturation has been investigated for at least 30 species, and 13 of these are Fabaceae species (Table 2). An increased fruit set resulting from the removal of flowers is consistent with the results of a previous experiment on Lotus corniculatus [18] and indicates the existence of the wide-choice mechanism: individuals with fewer fruit selection options 
show a higher fruit set rate than individuals with more fruit selection options. In our study, elderberry did not selectively mature ovules that grew into seedier fruits (Table 1). This result is consistent with a previous study of another bird-dispersed species (mahaleb cherry (Prunus mahaleb) [20]), and contradicts the results of three different self-dispersed species (Asphodelus albus [24]; Chamaecrista fasciculata (syn. Cassia fasciculata) [3], and Lotus corniculatus [18]) and three different wind-dispersed species (Asclepias speciosa [23], Campsis radicans [7], and Cochlospermum vitifolium [34]), in which parental plants selectively matured seedier fruits, and the authors concluded that seedier fruits are of superior quality. Our results and those of these previous studies support our hypothesis that selective maturation differentially affects the fruit traits of species depending on their dispersal mechanism.

Fruit size has been considered as being under conflicting selection [38]. Birds prefer fruits that contain a larger portion of edible parts, such as pericarps and arils, compared with its total seeds [35,36]. Supporting this, Guitián [20] reported that larger fruits were selectively matured, whereas seed number per fruit remained unchanged, after selective abortion in mahaleb cherry (P. mahaleb). However, larger fruits may not always be preferred by some bird dispersers. Some frugivorous birds have a limit to the size of fruits they can ingest [37] with gape width limiting the ability of frugivores to process large fruits [38]. Therefore, the effects of selective maturation on fruit traits may also depend on what species of birds disperse the fruit. We found limited effects of selective maturation on fruit sizes (Figure 1b). Individual seeds produced from selective maturation were often, but not always, larger or heavier than seeds produced after random removal (Table 2). However, we did not investigate individual seed size, which also affects dispersal efficiency, although a larger seed may not necessary be of higher fitness because of complex plant-animal interaction including seed dispersal [49] and post-dispersal predation [50]. Therefore, the effects of selective abortion should be investigated for a diversity of species with different plant-animal interactions. Currently, however, most studies are limited to wind- or selfdispersed species (Table 2), and further studies on broader taxa are needed to generalize our findings.

Self-thinning (i.e., spontaneous thinning by maternal plants $[18,30]$ ) or natural fruit abscission is a complex process influenced by hormonal regulation and source-sink interactions [30,51,52], but we did not investigate the potential effect of artificial hand-thinning on those interactions. Additionally, artificial removal of fruits may also trigger induced defense, which can also alter the chemical composition of fruits [53]. However, the current physiological studies on fruit abortion of wild plants are much less scarce than those on commercial cultivars that are used for fruit production. Therefore, further studies are needed to clarify the physiological mechanisms underlying selective abortion in wild plants. 


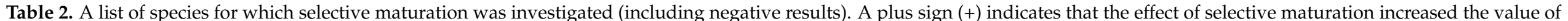

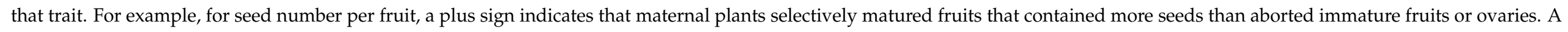

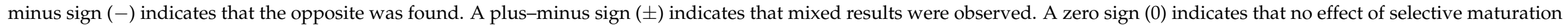

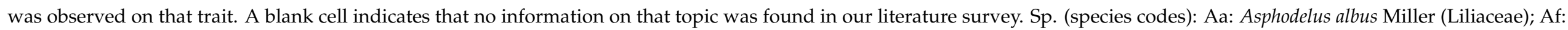

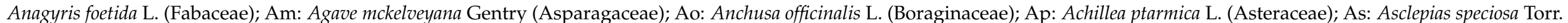

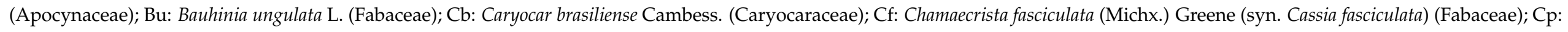

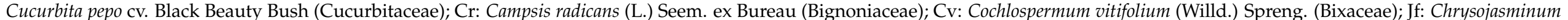

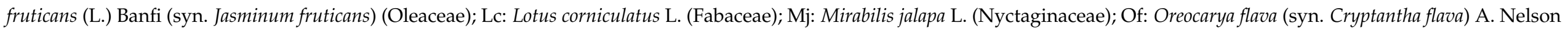

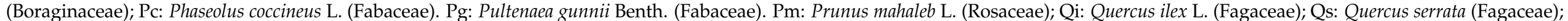

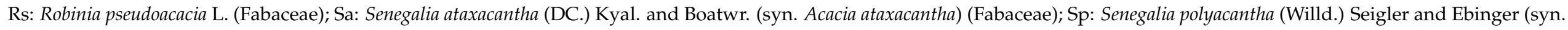

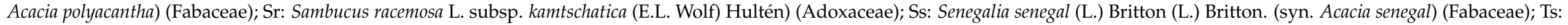
Triumfetta semitriloba Jacq. (Malvaceae); Ue: Ulex europaeus L. (Fabaceae); Ug: Ulex gallii (Fabaceae). Vc: Vachellia caven (syn. Acacia caven) (Molina) Seigler and Ebinger (Fabaceae).

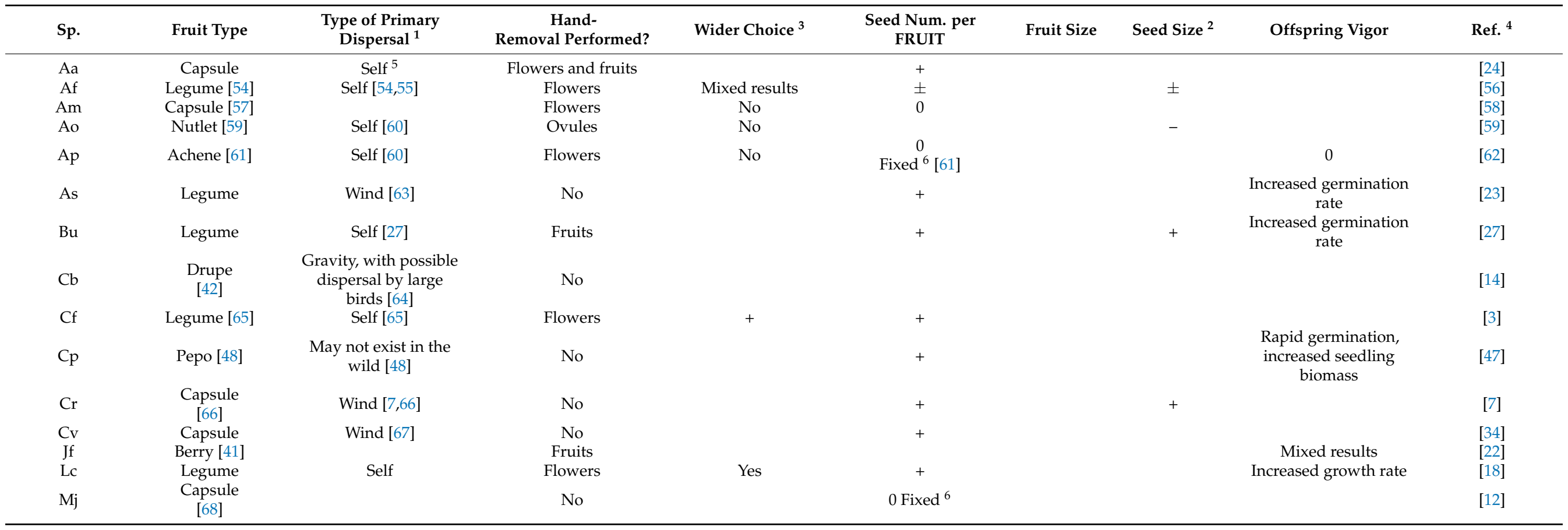


Table 2. Cont.

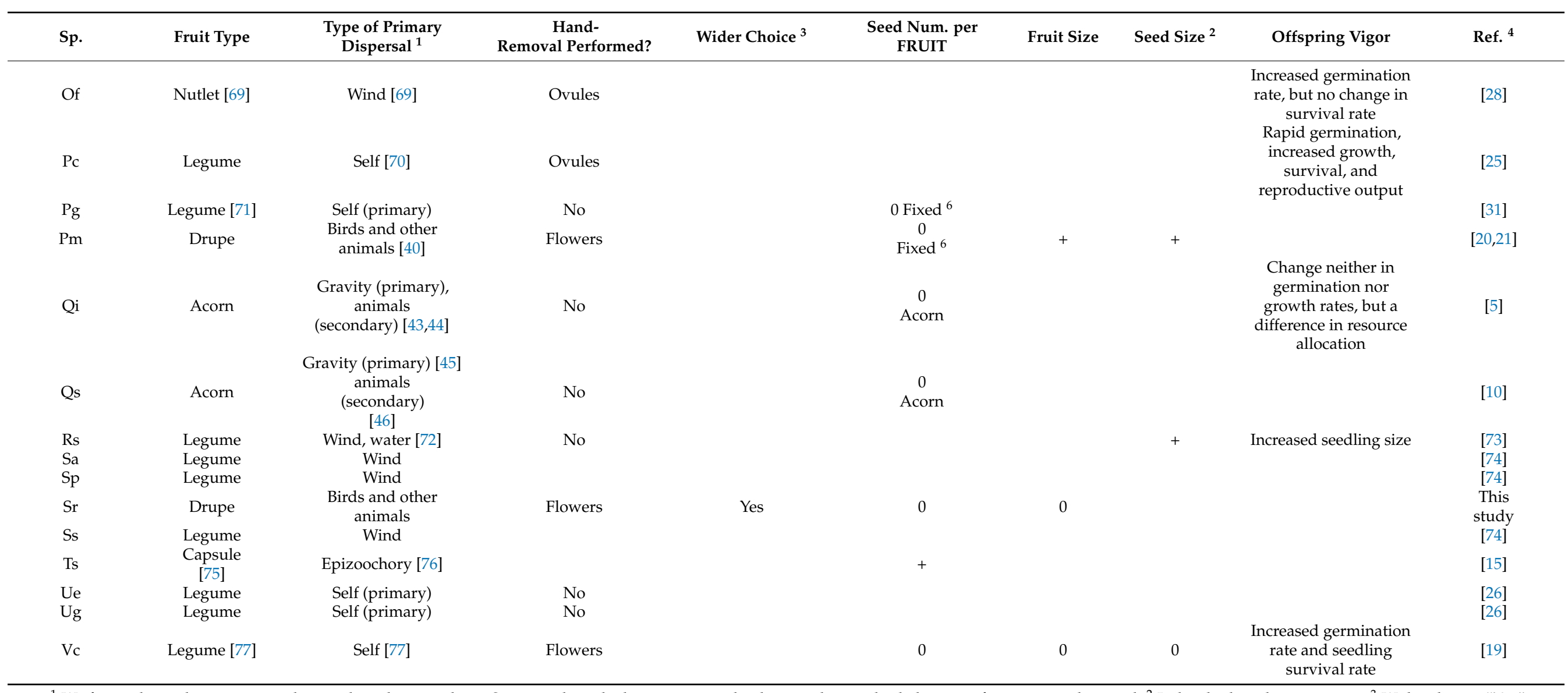

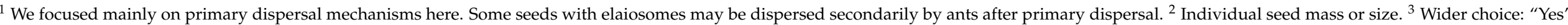

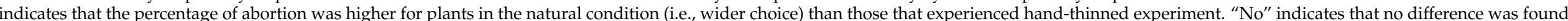

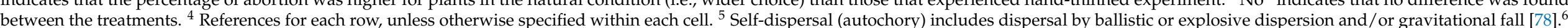
Single-ovuled fruits (including acorns). 


\section{Materials and Methods}

\subsection{Study Species and Sites}

Elderberry (Sambucus racemosa L. subsp. kamtschatica (E.L. Wolf) Hultén) (Adoxaceae) is a winter-deciduous shrub that grows on semi-open sites, such as forest gaps or forest edges. Flowers of this species are hermaphrodite [79]. Fruits of this species are dispersed birds $[80,81]$ and bears [80], and fruits of this particular subspecies is also dispersed by at least one bird species [82].

We conducted this study in 2019 on two sites in Obihiro City in Hokkaido, which is located in a cool-temperate region in Japan. The first site was in the Forest of Obihiro (Obihironomori), which is a plantation forest with a mixture of planted and regenerated trees ( $42^{\circ} 53^{\prime} \mathrm{N} 143^{\circ} 09^{\prime}$ E, altitude: $86 \mathrm{~m}$ a.s.l.). The second site was the Field Center of Animal Science and Agriculture at Obihiro University of Agriculture and Veterinary Medicine ( $45^{\circ} 52^{\prime} \mathrm{N} 143^{\circ} 10^{\prime} \mathrm{E}$, altitude: $79 \mathrm{~m}$ a.s.l.). The two sites were ca. $3 \mathrm{~km}$ apart from each other and were within $10 \mathrm{~km}$ from the Japan Meteorological Agency Obihiro Weather Station $\left(42^{\circ} 52^{\prime} \mathrm{N} 143^{\circ} 10^{\prime} \mathrm{E}\right.$, altitude: $76 \mathrm{~m}$ a.s.l.). The mean annual temperature and precipitation at the weather station during $1998-2017$ were $7.2^{\circ} \mathrm{C}$ and $937 \mathrm{~mm}$, respectively [83].

\subsection{Flower Removal Experiment}

In 2019, 24 individual trees (12 trees per site) were studied (Table 3). In the experimental garden, all of the individuals had been naturally dispersed and grown under or adjacent to windbreak trees surrounding fields planted with forage crops and pasture plants. The sample trees in the garden were located either in well-lit open spaces or in half-open spaces partially shaded by adjacent taller trees. In the Forest of Obihiro, we were not able to determine whether the sample trees were naturally grown or planted. All sample trees at the forest site were located in well-lit, open spaces. We performed a flower-removal experiment following [18]. To reduce sampling bias, we labeled 12 pairs (6 pairs at each site). Each pair consisted of two individuals of similar height that were located near each other within the same study site. From each of these pairs, we chose one individual as a treatment individual and the other as a control. In June 2019, when the flowers started wilting, we artificially removed $50 \%$ of the inflorescences with a pair of long-reach pruning scissors in the treatment group. If the individual had an odd number of inflorescences, we removed one inflorescence more than half. Inflorescences were removed by labeling two adjacent inflorescences as a single pair and then removing one of these inflorescences. The control plants were labeled with plastic labels, but did not manipulate them in any way.

Table 3. Sample sizes.

\begin{tabular}{|c|c|c|}
\hline & $\begin{array}{c}\text { Treatment } \\
\text { (Inflorescences 50\% Thinned) }\end{array}$ & Control \\
\hline Total number of trees investigated & 12 & 12 \\
\hline Median tree height $(\mathrm{m})$ & 2.98 & 2.69 \\
\hline Range of tree height $(\mathrm{m})$ & $1.70-3.83$ & $1.75-3.85$ \\
\hline Total number of infructescences sampled & 108 & 120 \\
\hline Total number of fruits counted for the calculation of the fruit set & 16,998 & 15,036 \\
\hline $\begin{array}{c}\text { Total number of fruit scars on the infructescences counted for the } \\
\text { calculation of the fruit set }\end{array}$ & 7544 & 11,626 \\
\hline Total number of fruits investigated for counting seed number per fruit & 1080 & 1162 \\
\hline $\begin{array}{l}\text { Total number of trees for which fruit sizes were measured (only for the } \\
\text { Forest site) }\end{array}$ & 3 & 3 \\
\hline Total number of infructescences used for size measurement & 30 & 30 \\
\hline Total number of fruits used for size measurement & 300 & 300 \\
\hline
\end{tabular}




\subsection{Fruit Set}

We sampled 5-10 infructescences per tree for both treatment and control individuals on 1-2 August 2019, once the fruits had matured (Table 3). Any differences in the number of infructescences per tree were due to the fact that some trees only produced a limited number of infructescences. The samples were stored in a refrigerator immediately after sampling until the measurements described below were performed. Following Sutherland [58], we counted the number of fruits attached to each infructescence and estimated the number of flowers by counting the scars on which ovules or immature fruits had attached but dropped before harvesting. We estimated the number of flowers as the sum of the number of fruits and the number of scars. The fruit set (i.e., fruit-to-flower ratio [58]) for each inflorescence was calculated with Equation (1):

$$
\text { Fruit set }=\frac{\text { fruit }}{\text { flower }}=\frac{\text { fruit }}{\text { fruit }+ \text { scars }}
$$

The fruits were sampled just after they matured, but because we did not use nets to prevent birds from removing the matured fruits, the fraction of fruits removed by birds before sampling is unknown.

\subsection{Fruit Size and Seed Number per Fruit}

Using the same set of infructescence samples for the fruit set measurements described above, we counted the number of seeds per fruit for selected fruits (Table 3). Ten healthy fruits were measured for each infructescence, and when the number of fruits on infructescences was less than ten, we sampled all the fruits on that infructescence. Fruit sizes were measured for 600 fruits from 60 infructescences from six individual trees from the Forest site (Table 3). Length was measured in two directions using digital calipers (resolution: $0.01 \mathrm{~mm}, \mathrm{CD}-15 \mathrm{AX}$, Mitutoyo Corp., Kawasaki, Japan). The first length ( $l$ ) was measured as the vertical distance between the bottom and the top of the fruit. The bottom of a fruit was defined as the place with which a fruit attaches to the infructescence. The second measurement was the width $(w)$, which was measured as the maximum horizontal width. We calculated the volume of each fruit $\left(V\left(\mathrm{~mm}^{3}\right)\right)$ as Equation (2):

$$
V=\frac{4}{3} \pi\left(\frac{l}{2}\right)\left(\frac{w}{2}\right)^{2}
$$

Size measurements were taken within two days of the sampling date. This limited the number of fruits for which size measurements were taken (Table 3), but it allowed us to finish the measurements when the fruits were still fresh. Therefore, fruit sizes were only measured for six individual trees at the forest site. For the rest of the trees, fruit size was not measured, but we subsequently counted the number of mature seeds for each fruit in August 2020 using fruit samples stored in a refrigerator. All of the datasets used in this article are available online as Supplementary Materials.

\subsection{Statistical Analysis}

All the statistical analyses described below were performed using the statistical software R v4.0.3 [84] and its packages ("ggbeeswarm" [85], "ggplot2" [86], and "lme4"[87]). The difference in fruit sets between the treatment and control groups was tested using a logistic regression analysis using the generalized linear mixed model (GLMM) employing binomial error distribution (i.e., the fruits either matured or dropped before maturation (as recognized by the scar)) with logit link function $[38,88]$ using the $\mathrm{R}$ function glmer (family = binomial $($ link $=$ "logit") $)$ [87] and setting the manipulation condition (either treatment or control) as the fixed effect. By referring to [89], we constructed the model of maximal random effects structure instead of choosing random variables via model selection, and we chose all the random effects justified by the design. In the present case, random effects were nested (i.e., inflorescences (infructescences), individuals (tree), pairs, 
and sites [either the forest or the university]). All these factors were included as nested random intercepts. The random slopes were the pairs and the sites. Because each individual or inflorescence experienced only a single manipulation condition, it was not possible to determine random slopes for these two variables (i.e., unidentifiable model [89]). As shown in the Results section, the difference was not significant $(p=0.0667)$, and reducing some random effects, such as excluding the site effect, often produced significant results $(p<0.05)$. However, because failure to include maximum random effects would have inflated the Type I error [89], we took a conservative approach. The differences in seed number per fruit between the two groups was tested using a GLMM (family = poisson (link = "log") with the same random effects as described above. The differences in fruit volume between the treatment and control trees were tested using the GLMM (family = Gamma (link = "log") with basically the same random effects as described above, with the modification that because the fruit volumes were measured only for the individuals from the forest site, site random effects were not incorporated for the analysis. We used a Gamma error distribution because it is used to describe continuous and positive variables $[49,90]$.

Supplementary Materials: All the dataset used in this article are available online at https:/ /www. mdpi.com/2223-7747/10/2/376/s1, S1: dataset.csv. The data may be used with proper citation of this article without contacting the authors.

Author Contributions: Conceptualization, K.K. and M.T.; methodology, K.K. and M.T.; formal analysis, K.K. and M.T.; investigation, K.K. and M.T.; writing-original draft preparation, K.K. and M.T.; writing —review and editing, K.K.; supervision, K.K.; project administration, K.K.; funding acquisition, K.K. All authors have read and agreed to the published version of the manuscript.

Funding: This work was funded by the Japan Society for the Promotion of Science (KAKENHI Grant Number 18K06406).

Institutional Review Board Statement: Not applicable.

Informed Consent Statement: Not applicable.

Data Availability Statement: The data presented in this study are available in the Supplementary Materials.

Acknowledgments: We thank Ray Deguchi, Riko Komamura, Ryusuke Kushida, and Kenta Morita for fieldwork assistances. We also thank staff members of Obihiro City Office, Obihiro Forest Hagukumu, and the Field Center of Animal Science and Agriculture of the Obihiro University of Agriculture and Veterinary Medicine, for giving us permissions to do the fieldworks at the study sites.

Conflicts of Interest: The authors declare no conflict of interest.

\section{References}

1. Janzen, D.H. A Note on Optimal Mate Selection by Plants. Am. Nat. 1977, 111, 365-371. [CrossRef]

2. Stephenson, A.G. Flower and fruit abortion: Proximate causes and ultimate functions. Ann. Rev. Ecol. Syst. 1981, 12, 253-279. [CrossRef]

3. Lee, T.D.; Bazzaz, F.A. Regulation of fruit and seed production in an annual legume, Cassia fasciculata. Ecology 1982, 63, 1363-1373. [CrossRef]

4. Collevatti, R.G.; Lopes, F.S.; Amaral, M.E.C. Reproductive success in the tropical weed Triumfetta semitriloba (Tiliaceae): Spatial and temporal variation in seed set. Rev. Biol. Trop. 1997, 1395-1399.

5. Díaz, M.; Møller, A.P.; Pulido, F.J. Fruit abortion, developmental selection and developmental stability in Quercus ilex. Oecologia 2003, 135, 378-385. [CrossRef]

6. Baskin, J.M.; Baskin, C.C. Effect of selective abortion on seed germination and post-germination performance of offspring. Seed Sci. Res. 2019, 29, 210-214. [CrossRef]

7. Bertin, R.I. Paternity and fruit production in trumpet creeper (Campsis radicans). Am. Nat. 1982, 119, 694-709. [CrossRef]

8. Wiens, D.; Calvin, C.; Wilson, C.; Davern, C.; Frank, D.; Seavey, S.R. Reproductive success, spontaneous embryo abortion, and genetic load in flowering plants. Oecologia 1987, 71, 501-509. [CrossRef]

9. Boavida, L.C.; Silva, J.P.; Feijó, J.A. Sexual reproduction in the cork oak (Quercus suber L). II. Crossing intra- and interspecific barriers. Sex. Plant Reprod. 2001, 14, 143-152. [CrossRef]

10. Tsuruta, M.; Kato, S.; Mukai, Y. Timing of premature acorn abortion in Quercus serrata Thunb. is related to mating pattern, fruit size, and internal fruit development. J. For. Res. 2011, 16, 492-499. [CrossRef] 
11. Ezoe, H. Excessive flower production as an anti-predator strategy: When is random flower abortion favored? Popul. Ecol. 2018, 60, 275-286. [CrossRef]

12. Niesenbaum, R.A. The effects of pollen load size and donor diversity on pollen performance, selective abortion, and progeny vigor in Mirabilis jalapa (Nyctaginaceae). Am. J. Bot. 1999, 86, 261-268. [CrossRef] [PubMed]

13. Pflugshaupt, K.; Kollmann, J.; Fischer, M.; Roy, B. Pollen quantity and quality affect fruit abortion in small populations of a rare fleshy-fruited shrub. Basic Appl. Ecol. 2002, 3, 319-327. [CrossRef]

14. Collevatti, R.G.; Estolano, R.; Garcia, S.F.; Hay, J.D. Seed abortion in the bat pollinated Neotropical tree species, Caryocar brasiliense (Caryocaraceae). Botany 2009, 87, 1110-1115. [CrossRef]

15. Collevatti, R.G.; Amara, M.E.C.; Lopes, F.S. Role of pollinators in seed set and a test of pollen limitation hypothesis in the tropical weed Triumfetta semitriloba (Tiliaceae). Rev. Biol. Trop. 1997, 1401-1407.

16. Díaz, M.; Pulido, F.J.; Møller, A.P. Herbivore effects on developmental instability and fecundity of holm oaks. Oecologia 2004, 139, 224-234. [CrossRef] [PubMed]

17. Buchholz, J.T. Developmental selection in vascular plants. Bot. Gaz. 1922, 73, 249-286. [CrossRef]

18. Stephenson, A.G.; Winsor, J.A. Lotus corniculatus regulates offspring quality through selective fruit abortion. Evolution 1986, 40, 453-458. [CrossRef]

19. Torres, C.; Eynard, M.C.; Aizen, M.A.; Galetto, L. Selective fruit maturation and seedling performance in Acacia caven (Fabaceae). Int. J. Plant Sci. 2002, 163, 809-813. [CrossRef]

20. Guitian, J. Why Prunus mahaleb (Rosaceae) produces more flowers than fruits. Am. J. Bot. 1993, 80, 1305-1309. [CrossRef]

21. Guitian, J. Selective fruit abortion in Prunus mahaleb (Rosaceae). Am. J. Bot. 1994, 81, 1555-1558. [CrossRef]

22. Thompson, J.D.; Dommée, B. Sequential variation in the components of reproductive success in the distylous Jasminum fruticans (Oleaceae). Oecologia 1993, 94, 480-487. [CrossRef]

23. Bookman, S.S. Evidence for selective fruit production in Asclepias. Evolution 1984, 38, 72-86. [CrossRef]

24. Obeso, J.R. Selective fruit and seed maturation in Asphodelus albus Miller (Liliaceae). Oecologia 1993, 93, 564-570. [CrossRef] [PubMed]

25. Rocha, O.J.; Stephenson, A.G. Effects of nonrandom seed abortion on progeny performance in Phaseolus coccineus L. Evolution 1991, 45, 1198-1208. [CrossRef] [PubMed]

26. Gutiérrez, D.; Menéndez, R.; Obeso, J.R. Effect of ovule position on seed maturation and seed weight in Ulex europaeus and Ulex gallii (Fabaceae). Can. J. Bot. 1996, 74, 848-853. [CrossRef]

27. Mena-AlÍ, J.I.; Rocha, O.J. Selective seed abortion affects the performance of the offspring in Bauhinia ungulata. Ann. Bot. 2005, 95, 1017-1023. [CrossRef] [PubMed]

28. Casper, B.B. Evidence for selective embryo abortion in Cryptantha flava. Am. Nat. 1988, 132, 318-326. [CrossRef]

29. Korbecka, G.; Klinkhamer, P.G.L.; Vrieling, K. Selective embryo abortion hypothesis revisited—a molecular approach. Plant Biol. 2002, 4, 298-310. [CrossRef]

30. Nakamura-Yamaguchi, A.; Kitahata, N.; Nishitani, C.; Takada, N.; Terakami, S.; Sawamura, Y.; Matsuyama, T.; Asami, T.; Nakano, T.; Saito, T.; et al. Pattern and trigger of fruit self-thinning in Japanese pears. Hortic. J. 2020, 89, 367-374. [CrossRef]

31. Burd, M. Offspring quality in relation to excess flowers in Pultenaea gunnii (Fabaceae). Evolution 2004, 58, 2371-2376. [CrossRef] [PubMed]

32. Burd, M. "Excess" flower production and selective fruit abortion: A model of potential benefits. Ecology 1998, 79, $2123-2132$. [CrossRef]

33. Lee, T.D. Patterns of fruit maturation: A gametophyte competition hypothesis. Am. Nat. 1984, 123, 427-432. [CrossRef]

34. Bawa, K.S.; Webb, C.J. Flower, fruit and seed abortion in tropical forest trees: Implications for the evolution of paternal and maternal reproductive patterns. Am. J. Bot. 1984, 71, 736-751. [CrossRef]

35. Howe, H.F.; Kerckhove, G.A.V. Nutmeg dispersal by tropical birds. Science 1980, 210, 925. [CrossRef]

36. Sobral, M.; Larrinaga, A.R.; Guitián, J. Do seed-dispersing birds exert selection on optimal plant trait combinations? Correlated phenotypic selection on the fruit and seed size of hawthorn (Crataegus monogyna). Evol. Ecol. 2010, 24, 1277-1290. [CrossRef]

37. Valenta, K.; Nevo, O. The dispersal syndrome hypothesis: How animals shaped fruit traits, and how they did not. Funct. Ecol. 2020, 34, 1158-1169. [CrossRef]

38. Alcántara, J.M.; Rey, P.J. Conflicting selection pressures on seed size: Evolutionary ecology of fruit size in a bird-dispersed tree, Olea europaea. J. Evol. Biol. 2003, 16, 1168-1176. [CrossRef] [PubMed]

39. Herrera, C.M.; Jordano, P. Prunus mahaleb and birds: The high-efficiency seed dispersal system of a temperate fruiting tree. Ecol. Monogr. 1981, 51, 203-218. [CrossRef]

40. Jordano, P.; Schupp, E.W. Seed disperser effectiveness: The quantity component and patterns of seed rain for Prunus mahaleb. Ecol. Monogr. 2000, 70, 591-615. [CrossRef]

41. Guitián, J.; Guitián, P.; Medrano, M. Floral biology of the distylous Mediterranean shrub Jasminum fruticans (Oleaceae). Nord. J. Bot. 1998, 18, 195-201. [CrossRef]

42. De Araujo, F.D. A review of Caryocar brasiliense (caryocaraceae)—an economically valuable species of the central brazilian cerrados. Econ. Bot. 1995, 49, 40-48. [CrossRef]

43. Gómez, J.M. Spatial patterns in long-distance dispersal of Quercus ilex acorns by jays in a heterogeneous landscape. Ecography 2003, 26, 573-584. [CrossRef] 
44. Pulido, F.J.; Díaz, M. Regeneration of a Mediterranean oak: A whole-cycle approach. Écoscience 2016, 12, 92-102. [CrossRef]

45. Masaki, T.; Nakashizuka, T.; Niiyama, K.; Tanaka, H.; Iida, S.; Bullock, J.M.; Naoe, S. Impact of the spatial uncertainty of seed dispersal on tree colonization dynamics in a temperate forest. Oikos 2019, 128, 1816-1828. [CrossRef]

46. Zeng, D.; Swihart, R.K.; Zhao, Y.; Si, X.; Ding, P. Cascading effects of forested area and isolation on seed dispersal effectiveness of rodents on subtropical islands. J. Ecol. 2019, 107, 1506-1517. [CrossRef]

47. Winsor, J.A.; Davis, L.E.; Stephenson, A.G. The relationship between pollen load and fruit maturation and the effect of pollen load on offspring vigor in Cucurbita pepo. Am. Nat. 1987, 129, 643-656. [CrossRef]

48. Kistler, L.; Newsom, L.A.; Ryan, T.M.; Clarke, A.C.; Smith, B.D.; Perry, G.H. Gourds and squashes (Cucurbita spp.) adapted to megafaunal extinction and ecological anachronism through domestication. Proc. Natl. Acad. Sci. USA 2015, 112, 15107-15112 [CrossRef] [PubMed]

49. Case, S.B.; Tarwater, C.E. Functional traits of avian frugivores have shifted following species extinction and introduction in the Hawaiian Islands. Funct. Ecol. 2020, 34, 2467-2476. [CrossRef]

50. Gómez, J.M. Bigger is not always better: Conflicting selective pressures on seed size in Quercus ilex. Evolution 2004, 58, 71-80. [CrossRef] [PubMed]

51. Costa, G.; Botton, A.; Vizzotto, G. Fruit thinning: Advances and trends. In Hortic. Rev.; Warrington, I., Ed.; Wiley: Hboken, NJ, USA, 2018; Volume 46, pp. 185-226.

52. Einhorn, T.C.; Arrington, M. ABA and Shading Induce 'Bartlett' Pear Abscission and Inhibit Photosynthesis but Are Not Additive. J. Plant Growth Regul. 2018, 37, 300-308. [CrossRef]

53. Kundu, A.; Vadassery, J. Chlorogenic acid-mediated chemical defence of plants against insect herbivores. Plant Biol. 2019, 21, 185-189. [CrossRef] [PubMed]

54. Valtueña, F.J.; Ortega-Olivencia, A.; Rodríguez-Riaño, T. Germination and seed bank biology in some Iberian populations of Anagyris foetida L. (Leguminosae). Plant Syst. Evol. 2008, 275, 231. [CrossRef]

55. Valtueña, F.J. Personal Communication; Universidad de Extremadura: Badajoz, Extremadura, Spain, 2020.

56. Valtueña, F.J.; Ortega-Olivencia, A.; Rodríguez-Riaño, T. Regulation of fruit and seed set in Anagyris foetida L. (Fabaceae): The role of intrinsic factors. Plant Biosyst.-Int. J. Deal. All Asp. Plant Biol. 2012, 146, 190-200. [CrossRef]

57. Hodgson, W. Agavaceae Agave Family: Part One: Agave L. Century Pant, Maguey. J. Ariz.-Nev. Acad. Sci. 1999, $32,1-21$.

58. Sutherland, S.D. Why hermaphroditic plants produce many more flowers than fruits: Experimental tests with Agave mckelveyana. Evolution 1987, 41, 750-759. [CrossRef]

59. Andersson, S. No evidence for selective seed maturation in Anchusa officinalis (Boraginaceae). Oikos 1990, 57, 88-93. [CrossRef]

60. Andersson, S. Personal Communication; Lund University: Lund, Sweden, 2020.

61. Andersson, S. The cost of floral attractants in Achillea ptarmica (Asteraceae): Evidence from a ray removal experiment. Plant Biol. 1999, 1, 569-572. [CrossRef]

62. Andersson, S. The potential for selective seed maturation in Achillea ptarmica (Asteraceae). Oikos 1993, 66, 36-42. [CrossRef]

63. Bookman, S.S. Costs and benefits of flower abscission and fruit abortion in Asclepias speciosa. Am. J. Bot. 1983, 70, 897-905. [CrossRef]

64. Collevatti, R.G.; Grattapaglia, D.; Hay, J.D. High resolution microsatellite based analysis of the mating system allows the detection of significant biparental inbreeding in Caryocar brasiliense, an endangered tropical tree species. Heredity 2001, 86, 60-67. [CrossRef]

65. Lee, T.D. Effects of seed number per fruit on seed dispersal in Cassia fasciculata (Caesalpiniaceae). Bot. Gaz. 1984, 145, 136-139. [CrossRef]

66. Chachalis, D.; Reddy, K.N. Factors affecting Campsis radicans seed germination and seedling emergence. Weed Sci. 2000, 48, 212-216. [CrossRef]

67. Bawa, K.S.; Frankie, G.W. Cochlospermum vitifolium (Poro-poro, Cochlospermum, Silk tree, cotton tree). In Costa Rican natural history; Janzen, D.H., Ed.; University of Chicago Press: Chicago, IL, USA, 1983; pp. 215-216.

68. Berardi, A.E.; Frey, F.M.; Denton, E.M.; Wells, J.H. Betalain color morphs exhibit differential growth, defensive ability, and pollen tube growth rates in Mirabilis jalapa (Nyctaginaceae). Int. J. Plant Sci. 2013, 174, 1229-1238. [CrossRef]

69. Casper, B.B. Spatial patterns of seed dispersal and postdispersal seed predation of Cryptantha flava (Boraginaceae). Am. J. Bot. 1987, 74, 1646-1655. [CrossRef]

70. Cortés-Flores, J.; Andresen, E.; Cornejo-Tenorio, G.; Ibarra-Manríquez, G. Fruiting phenology of seed dispersal syndromes in a Mexican Neotropical temperate forest. For. Ecol. Manag. 2013, 289, 445-454. [CrossRef]

71. de Kok, R.P.J.; West, J.G. A revision of the genus Pultenaea (Fabaceae). 3. The eastern species with recurved leaves. Aust. Syst. Bot. 2004, 17, 273-326. [CrossRef]

72. Morimoto, J.; Kominami, R.; Koike, T. Distribution and characteristics of the soil seed bank of the black locust (Robinia pseudoacacia) in a headwater basin in northern Japan. Landsc. Ecol. Eng. 2010, 6, 193-199. [CrossRef]

73. Susko, D.J. Effect of ovule position on patterns of seed maturation and abortion in Robinia pseudoacacia (Fabaceae). Can. J. Bot. 2006, 84, 1259-1265. [CrossRef]

74. Tybirk, K. Pollination, breeding system and seed abortion in some African acacias. Bot. J. Linn. Soc. 1993, 112, 107-137. [CrossRef]

75. Jara Guerrero, A.K. Ecología de la dispersión de plantas en los bosques secos del suroccidente Ecuatoriano. PhD Dissertation, Universidad Politécnica de Madrid, Madrid, Spain, 2014. 
76. Francis, J.K. Wildland Shrubs of the United States and Its Territories: Thamnic Descriptions, Volume 1.; U.S. Department of Agriculture, Forest Service: Fort Collins, CO, USA, 2004.

77. Couturier, E. Folded isometric deformations and banana-shaped seedpod. Proc. R. Soc. A Math. Phys. Eng. Sci. 2016, 472, 20150760. [CrossRef] [PubMed]

78. Howe, H.F.; Smallwood, J. Ecology of seed dispersal. Ann. Rev. Ecol. Syst. 1982, 13, 201-228. [CrossRef]

79. Inoue, T.; Kato, M.; Kakutani, T.; Suka, T.; Itino, T. Insect-flower relationship in the temperate deciduous forest of Kibune, Kyoto: An overview of the flowering phenology and the seasonal pattern of insect visits. Contrib. Biol. Lab. Kyoto Univ. 1990, 27, 377-463.

80. Traveset, A.; Willson, M.F. Effect of birds and bears on seed germination of fleshy-fruited plants in temperate rainforests of southeast Alaska. Oikos 1997, 80, 89-95. [CrossRef]

81. Burns, K.C. A simple null model predicts fruit-frugivore interactions in a temperate rainforest. Oikos 2006, 115, 427-432. [CrossRef]

82. Fujimaki, Y. Food habit of hazel grouse in Hokkaido, Japan. J. Yamashina Inst. Ornithol. 2002, 34, 73-79. [CrossRef]

83. Japan Meteorological Agency. Available online: https://www.jma.go.jp (accessed on 2 March 2018).

84. R Core Team. R: A Language and Environment for Statistical Computing; R Foundation for Statistical Computing: Vienna, Austria, 2020.

85. Clarke, E.; Sherrill-Mix, S. Ggbeeswarm: Categorical Scatter (Violin Point) Plots. 2017.

86. Wickham, H. ggplot2: Elegant Graphics for Data Analysis; Springer: New York, NY, USA, 2016.

87. Bates, D.; Mächler, M.; Bolker, B.; Walker, S. Fitting linear mixed-effects models using lme4. J. Stat. Softw. 2015, 67, 48. [CrossRef]

88. Koyama, K.; Shirakawa, H.; Kikuzawa, K. Redeployment of shoots into better-lit positions within the crowns of saplings of five species with different growth patterns. Forests 2020, 11, 1301. [CrossRef]

89. Barr, D.J.; Levy, R.; Scheepers, C.; Tily, H.J. Random effects structure for confirmatory hypothesis testing: Keep it maximal. J. Mem. Lang. 2013, 68, 255-278. [CrossRef]

90. Deguchi, R.; Koyama, K. Photosynthetic and morphological acclimation to high and low light environments in Petasites japonicus subsp. giganteus. Forests 2020, 11, 1365. [CrossRef] 